\title{
The Influence of Initial Management and Family Stress on Metabolic Control in Children with Type 1 Diabetes
}

\author{
Irén Tiberg $^{1,2,3}$, Inger Hallström ${ }^{1,2}$, Annelie Carlsson ${ }^{3}$ \\ ${ }^{1}$ Division of nursing, Department of Health Science, Lund University, Lund, Sweden; ${ }^{2}$ The Swedish Institute for Health Sciences, \\ Lund, Sweden; ${ }^{3}$ Department of Pediatrics, Lund University Hospital, Lund, Sweden. \\ Email: \{iren.tiberg, inger.hallstrom, annelie.carlsson\}@med.lu.se
}

Received September $10^{\text {th }}, 2010$; revised September $22^{\text {nd }}, 2010$; accepted September $25^{\text {th }}, 2010$.

\begin{abstract}
The aim was to assess whether temporal changes in the initial management for children diagnosed with type 1 diabetes over a ten year period affected metabolic control two years after diagnosis. A further aim was to investigate if social factors, registered at diagnosis, had an impact on metabolic control two years after diagnosis. During the years 1997-2006, 247 children and adolescents were diagnosed with type 1 diabetes at a University Hospital in Sweden. The analysed data included HbA1c, pH at diagnosis, initial intravenous insulin infusion and length of hospital stay at diagnosis, subcutaneous insulin type, number of diabetes check-up visits, emergency visits, re-admissions and social factors. Length of hospital stay decreased significantly over the ten year period. Neither hospital stay nor differences in insulin treatment was significantly correlated with children's metabolic control over time. Length of hospital stay was not related with families' social stress situation. However, girls in families with more family stress at the time of diagnosis had higher HbA1c during follow-up than girls with less family stress or boys. Factors of importance for the child's long-term metabolic control need to be further investigated so the initial management can be tailored to each individual family's needs. This would imply an effective utilization of both families' and health care resources.
\end{abstract}

Keywords: Type 1 Diabetes, Disease Management, Patient Admission, Life Stress, Hemoglobin A1c

\section{Introduction}

In Sweden, most children with newly diagnosed type 1 diabetes are admitted to hospital for about 1-3 weeks and receive intravenous insulin infusion the first days, in line with the Swedish national care program for pediatric and adolescent diabetes [1]. The first national care program guidelines were presented in 1982. Since then, these guidelines have become standard of care in Sweden and have led to important improvements in Swedish pediatric diabetes care. In other parts of the world, duration of hospital admission and stay after the initial diagnosis varies greatly, from several weeks to a few days or, alternatively, on an outpatient basis only [2-4]. The overall trend is for shorter lengths of stay and/or exclusively outpatient management [2-6]. A recent review, comparing hospital based and home based care, showed that studies were too limited to reach clear conclusions, but home based care did not seem to lead to any disadvan- tages concerning metabolic control or psychological outcomes [7]. Re-admission and emergency visits rates have the potential, besides $\mathrm{HbAlc}$ to be utilised as an evaluation for the efficiency of treatment or education program [8].

Metabolic acidosis of clinical relevance is defined in the Swedish national program as $\mathrm{pH}<7.30$ [1]. Routines for initial intravenous insulin treatment vary between countries to only include children who are acutely ill at diagnosis [6,9], to include almost all children diagnosed with type 1 diabetes. Intravenous insulin infusion is recommended one or two days before start with subcutaneous treatment even if the child is not acutely ill. The argument for intravenous treatment is that it facilitates a stabile plasma glucose level during the first days and that it might preserve beta cell function [10]. On the other hand it is argued that preserved beta cell function is likely to relate to a normal glucose level rather than to how the insulin is administrated or the quantity of insulin 
given $[11,12]$.

To maintain metabolic control, major adjustments are needed by the family, requiring time and attention [13]. Family stress and social family background are most important factors concerning metabolic control [13-16]. Parental marital status, rather than socioeconomic status have been suggested to better capture family factors that impact the child's metabolic control, where biological parents who lived together were associated with lower $\mathrm{HbA1c}$ compared to alternative family arrangements [17]. In order to direct resources, it is of interest if social factors at the time for diagnosis can separate more vulnerable children who might be in risk to develop poor metabolic control. To guarantee quality in health care, all elements of the care need to be followed and evaluated with focus on outcomes $[1,18]$.

The aim of our study was to assess whether temporal changes in the initial management for children diagnosed with type 1 diabetes over a ten year period affected metabolic control two years after diagnosis. A further aim was to investigate if social factors, registered at diagnosis, had an impact on metabolic control two years after diagnosis.

\section{Methods}

\subsection{Participants}

The study was carried out at the Department of Pediatrics at the University Hospital in Lund. The department's diabetes unit cares for about 270 children (in 2010) with type 1 diabetes, between the ages of $0-18$ years. During the years 1997 to 2006,250 children aged between 0-16 years were diagnosed with type 1 diabetes and were recorded. The data, for a ten year period was retrieved from the hospital's patient administrative system, patient's records and from a national quality registry, the Swedish Childhood Diabetes Registry SWEDIABKIDS [19]. Data from three children were excluded as they moved from the hospital's catchments area shortly after diagnosis. Data concerning age, $\mathrm{pH}$ at diagnosis, duration of initial intravenous infusion, total days for hospital stay at diagnosis, length of overnight and daytime only hospital stay, insulin type, number of regular diabetes check visits to physicians, metabolic control measured as HbAlc, number of emergency visits and re-admissions related to the diabetes, were registered prospectively.

\subsection{Outcome measurements}

Data concerning social factors, assumed to impact the child's life stress [13-16] were retrospectively retrieved from patients' records during the time of primary hospital

This study was supported by The Swedish Institute for Health Sciences, The faculty of Medicine, University of Lund, The Swedish research council, The Swedish diabetes foundation and The Region of Skåne admission in connection with the diagnosis. Social factors were if the child had a) problems at school b) illness apart from type 1 diabetes and c) no or minimal contact with one parent. Social factors assumed to have an impact on the family stress and indirectly on the child's situation were if there was a) illness in the family b) unemployed parents c) parents on long-term sick-leave d) financial problems in the family and e) parents with criminal record.

Each social factor was registered if it was not present (0), was present for one family member (1) or present for two family members (2) and summarised for each family with parental marital status (parents living together (0), parents separated (1)). The number of siblings living in the family was registered with the assumption that more siblings might have an impact on the general family stress [20]. The summarised social factors, further described as family stress, were dichotomized into children who had no or one family stress factor and children who had two or more family stress factors. The number of siblings was also dichotomized into children who had no or one sibling and children who had two or more siblings. The groups were divided from the assumption that it is a cumulative family stress that is likely to impact the child's metabolic control.

$\mathrm{HbAlc}$ at six, 12 and 24 months after diagnosis was recorded. For cases without recorded HbAlc at the designated time points ( 81 of total 730 values), values were interpolated between the two closest registrations. The interpolated value was weighted according to time interval between each anchoring registration at six, 12 and 24 months, respectively. Data were analysed both for the whole cohort and for each year. The trends are presented in a ten-year interval, year 1997 and 2006 or five-year interval, year 1997, 2002 and 2006. For some variables, groups were too small to be analysed for each year and were in those cases analysed in five year periods, 1997-2001 and 2002-2006. The study was approved by the Research Ethics Committee at Lund University (LU 305/2007).

\subsection{Statistical methods}

All analysis were conducted using SPSS ${ }^{\mathrm{TM}}$ for Windows (version 14.0) and $p$-values $<0.05$ were considered statistical significant. A descriptive analysis was used to present the children's age and $\mathrm{pH}$ at diagnosis as well as trends concerning insulin treatment, hospital stay and out-patient visits. Continuous variables were checked for distributional characteristics and, when found not to be normally distributed, non-parametric methods were used. In those analyses $\mathrm{HbA} 1 \mathrm{c}$ was dichotomized, a cut point at $7.1 \%$ was chosen due to Diabetes Control and Complications Trial (DCCT) mean $\mathrm{HbAl}$ c for the group with 
intensive treatment [21]. Another argument for the cut point was that it separated $20 \%$ of the children with the highest $\mathrm{HbA1c}$ values. Swedish $\mathrm{HbA1c}$ values are $1 \%$ lower than National Glycohemoglobin Standardization Program (NGSP) and DCCT [22].

Trends in the length of intravenous treatment and hospital stay were analyzed with Mann-Whitney test. The relationship between initial intravenous treatment and $\mathrm{HbA1c}$ at six and 12 months was analyzed with Spearman's rank correlation. This was not performed with values of the 24 months due to the assumption that a possible preserved beta cell function was most likely within the first year [23]. Spearman's rank correlation was also used to investigate the relation between days of hospital stay and HbAlc at six, 12 and 24 months. Since we found an association between hospital stay and metabolic control further analysis with possible predictors of time of hospital stay were analyzed using linear regression with family stress, age divided into four groups and $\mathrm{pH}$ at diagnosis as independent variables. Linear regression was used to analyze possible predictors of $\mathrm{HbAlc}$ with family stress, age groups and $\mathrm{pH}$ at diagnosis.

One-way ANOVA was used to compare insulin type from the time of diagnosis and HbAlc at 24 months. According to the most commonly used subcutaneous insulin types, insulin type was divided in three groups, multiple injections with a) human insulin, b) insulin analogues for meals combined with NPH and c) insulin analogues for both meals and basal insulin. Due to multiple comparisons Bonferroni correction was applied.

The influence of family stress on the development of $\mathrm{HbAlc}$ from six to 24 months was investigated using repeated measures ANOVA. The dichotomized variables concerning family stress and siblings were entered as between-subject factors together with age and gender. Possible predictors of $\mathrm{HbAlc}$ values $>7.1 \%$ at 24 months were analyzed using multivariate logistic regression (backward, likelihood ratio) with family stress and siblings as independent variables. To evaluate the influence on HbAlc of biological parents living together or not at diagnosis, a subgroup analysis was performed comparing the children with no or one family stress factor. For this group repeated measures ANOVA was used with parents' cohabitation as a between-subject factor. Trends in emergency visits and re-admission were analyzed with T-test.

\section{Results}

Of the 247 children included (130 boys and 117 girls) all except one, were admitted to hospital. The number of children included each year and age at diagnosis is presented in Table 1.
Table 1. The number of children included each year and age at diagnosis

\begin{tabular}{ccccc}
\hline Year & $\mathrm{n}$ & Age median & Min-Max & $\begin{array}{c}\text { Inter quartile } \\
\text { range }\end{array}$ \\
\hline 1997 & 25 & 9.94 & $2.63-16.50$ & 5.43 \\
1998 & 17 & 8.11 & $0.73-15.04$ & 6.29 \\
1999 & 26 & 10.45 & $1.71-15.80$ & 6.24 \\
2000 & 20 & 8.70 & $0.95-15.80$ & 7.20 \\
2001 & 28 & 8.86 & $1.71-14.79$ & 6.47 \\
2002 & 22 & 10.25 & $1.40-15.52$ & 6.46 \\
2003 & 32 & 8.80 & $0.74-14.92$ & 6.59 \\
2004 & 21 & 9.51 & $0.93-15.56$ & 7.12 \\
2005 & 26 & 9.85 & $1.26-15.66$ & 6.13 \\
2006 & 30 & 9.94 & $2.23-15.23$ & 6.39 \\
Total & 247 & 9.11 & & \\
\hline
\end{tabular}

Seventy-five percent of the children had $\mathrm{pH} \geq 7.30$ at diagnosis. In $7 \%$ of the cases, values were missing, with each of these children with a relatively mild presentation. Ninety-four percent of the children received intravenous insulin treatment initially. Length of insulin infusion in 1997 was median 43 hours (min-max 15-135) and in 2006,53 hours $(24-123)(p=0.106)$. The time for hospital stay decreased from a mean of 19.8 days (SD 3.64) in 1997 to 13.6 days (SD 3.29) in $2006(p \leq 0.000)$. The time of hospital stay before the child left the ward daytime, e.g. a brief home visit with the parents, was mean 8.5 days (SD 2.29) in 1997 and 7.0 days in 2006 (SD 2.05) $(p=0.028)$. The number of days before the child spent a night at home, while still being under care at the hospital, decreased from mean 12.8 days (SD 3.22) in 1997 to 8.4 days $(\mathrm{SD} 2.36)$ in $2006(p \leq 0.000)$.

After the intravenous treatment, all children were prescribed multiple subcutaneous injections. The dominant insulin type for newly diagnosed children in 1997 (24/25 children) was human insulin both for meals (regular) and basal insulin (NPH). In 2002 most children (20/22) still started with human insulin's but changed during the follow-up to insulin analogues for meals combined with NPH. In 2006 all of the children (30/30) started on insulin analogues, rapid and basal insulin, after intravenous infusion. Insulin pump therapy was introduced to 2-4 children yearly during the follow-up period. The number of regular diabetes visits in the two year follow-up time showed a mean of 10.7 visits (SD 1.97) in 1997 and 11.6 (SD 2.58) in 2002, year 2006 differed from earlier years with a mean of 8.2 visits (SD 1.84). Children diagnosed during the first five year period (1997-2001) had a mean of 0.57 emergency visits during follow-up and during the last five year period (2002-2006) $0.30(p=0.019)$. Children diagnosed during the first five year period had a mean of 0.36 diabetes related re-admissions and 0.42 the last five year period $(p=0.633)$. The most common reason for re-admission was gastrointestinal illness associ- 
ated with difficulties in maintaining the glucose levels.

There was no correlation between length of intravenous insulin treatment and $\mathrm{HbAlc}$ at six $(n=198)$ or 12 $(n=199)$ months ( $r=0.065$ and $0.033, p=0.366$ and 0.643$)$. More days of in hospital care before the child spend a night at home correlated significantly with higher $\mathrm{HbAlc}$ at six months (Table 2) and were likely to be explained by age at diagnosis. Younger children had more days of hospital stay and children younger than six years were also the group with highest $\mathrm{HbAlc}$ values at six and 12 months, but not at 24 months (Figure 1). Age and pH at diagnosis predicted days of hospital stay but not family stress (Table 3). There was no difference between groups concerning subcutaneous insulin type at diagnosis and $\mathrm{HbAlc}<7.1$ or $\geq 7.1 \%$ at 24 months $(p=0.434)$.

When analysing family stress and the number of siblings, the linear progression of $\mathrm{HbA} 1 \mathrm{c}$ due to diabetes duration did not differ between the groups. However, mean $\mathrm{HbA} 1 \mathrm{c}$ from six, 12 and 24 months differed significantly with higher $\mathrm{HbAlc}$ for girls with more than one family stress factor than girls with less family stress or boys (Table 4). HbA1c $\geq 7.1 \%$ at 24 months could not be explained by family stress or the number of siblings $(p=0.407)$. Children's metabolic control, in the group with no or one family stress factor, where the biological parents were separated $(n=33)$ did not differ from those with parents living together $(n=173)$ with a mean $\mathrm{HbAlc}$ from the follow-up period (six, 12 and 24 months) $6.217 \%$ (SD 0.95) and 6.212\% (SD 0.95) $(p=0.981)$.

\section{Discussion}

The aim of this study was to investigate the initial management and the influence on metabolic control. Length of hospital stay decreased significantly over the ten year period and resulted in similar metabolic outcomes during the two year follow-up, which was in line with earlier studies $[12,24,25]$. Furthermore, no changes in re-admissions and fewer emergency visits over time were found. These findings suggest that time for hospital stay is not likely to be a determining factor concerning families' possibilities to manage the diabetes treatment. However, during the analysed ten year period, insulin types have changed from human insulin to insulin analogues. This might have influenced the results as use of insulin analogues compared to human insulin was associated with reduced risk of hypoglycaemia and improved metabolic control for adults and with a diabetes duration of at least 12 months [26]. Different insulin types did not separate children with the highest HbAlc values in the present study.

Length of intravenous treatment was not shown to determine children's metabolic control over time. Earlier studies report that initial intravenous treatment was given to children who were acutely ill or dehydrated at diagnosis $[6,9,12,27]$. In our study, $94 \%$ initially received in

Table 2. Correlation between total days of hospital stay, days before the child left the ward daytime, days of overnight and HbA1c at six, 12 and 24 months.

\begin{tabular}{llll}
\hline Groups & $\begin{array}{l}\text { HbA1c } \% \\
\text { at six } \\
\text { months }\end{array}$ & $\begin{array}{l}\text { HbA1c } \% \\
\text { at } 12 \\
\text { months }\end{array}$ & $\begin{array}{l}\text { HbA1c } \% \\
\text { at } 24 \\
\text { months }\end{array}$ \\
\hline $\begin{array}{l}\text { Total days of hospital } \\
\text { stay }\end{array}$ & & & \\
Correlation & & & \\
coefficient & 0.094 & 0.047 & -0.013 \\
Significance* & 0.146 & 0.469 & 0.843 \\
N & 243 & 244 & 240 \\
Days before the child & & & \\
left the ward daytime & & & \\
Correlation & & -0.044 & 0.006 \\
coefficient & 0.098 & 0.531 & 0.930 \\
Significance* & 0.159 & 208 & 204 \\
N & 207 & & \\
Days of overnight & & & \\
hospital stay & & & \\
Correlation & & 0.022 & 0.001 \\
coefficient & 0.162 & 0.740 & 235 \\
Significance* & $0.012 *$ & 238 & \\
N & & & \\
\hline
\end{tabular}

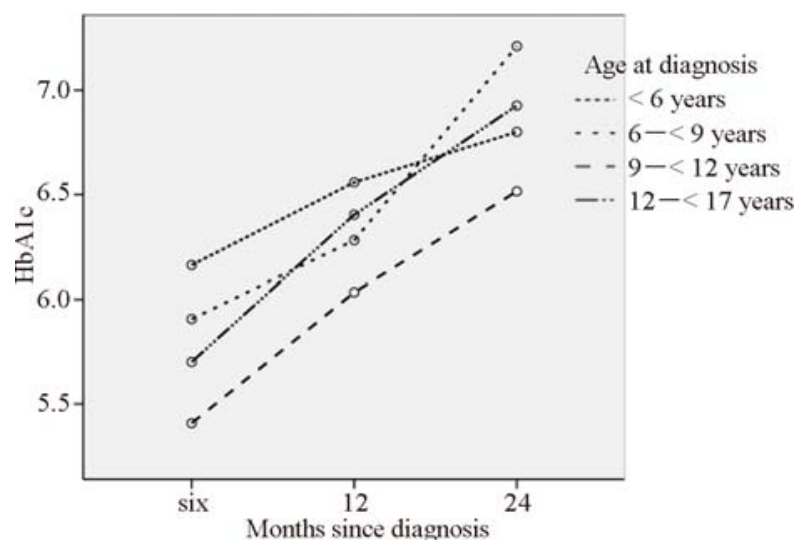

Figure 1. Mean HbA1c (\%) at six, 12 and 24 months in relation to age at diagnosis, divided into four groups

Table 3. Possible predictors of days before the child could leave hospital for the night and possible predictors for HbA1c at six months.

\begin{tabular}{lllll}
\hline Model & $\begin{array}{c}\text { Dependent } \\
\text { variable }\end{array}$ & $\begin{array}{c}\text { Independent } \\
\text { variable }\end{array}$ & $\begin{array}{c}\text { B- } \\
\text { value }\end{array}$ & $\begin{array}{c}\text { P- } \\
\text { value }\end{array}$ \\
\hline Adjusted & $\begin{array}{l}\text { Days of } \\
\text { hospital stay }\end{array}$ & $\begin{array}{l}\text { Family stress } \\
\text { Age at diagnosis } \\
\text { pH at diagnosisi }\end{array}$ & -0.169 & 0.592 \\
$\mathrm{R}^{2}=0.070$ & & & & 0.004 \\
& & pH at diagnosis & & 0.171 \\
Adjusted & HbA1c at six & $\begin{array}{l}\text { Family stress } \\
\text { Age at diagnosis }\end{array}$ & -0.043 & 0.000 \\
$\mathrm{R}^{2}=0.025$ & months & & & \\
& & &
\end{tabular}


Table 4 Comparisons of mean HbA1c at six, 12 and 24 months after diagnosis between groups based on family stress, gender and sibling.

\begin{tabular}{|c|c|c|c|c|}
\hline Groups (n) & $\begin{array}{l}\text { Mean } \\
\text { HbA1c \% }\end{array}$ & SD & Significance* & $95 \% \mathrm{Cl}$ \\
\hline Family stress & & & $P=0.065$ & \\
\hline No or one family stress factor (210) & $6.208^{\mathrm{a}}$ & 1.07 & & $6.061-6.356$ \\
\hline Two or more family stress factors (35) & $6.579^{\mathrm{a}}$ & 1.05 & & $6.214-6.945$ \\
\hline Gender & & & $P=0.056$ & \\
\hline Girl (117) & $6.585^{\mathrm{a}}$ & 1.56 & & $6.295-6.874$ \\
\hline Boy (130) & $6.203^{\mathrm{a}}$ & 1.50 & & $5.938-6.468$ \\
\hline Siblings & & & $P=0.085$ & \\
\hline No or one sibling (165) & $6.222^{\mathrm{a}}$ & 1.51 & & $5.986-6.457$ \\
\hline Two or more siblings (80) & $6.566^{\mathrm{a}}$ & 1.41 & & $6.251-6.881$ \\
\hline Family stress/gender & & & $P=0.020^{*}$ & \\
\hline No or one family stress factor/Girl (100) & $6.167^{\mathrm{a}}$ & 1.05 & & $5.961-6.373$ \\
\hline No or one family stress factor/Boy (112) & $6.250^{\mathrm{a}}$ & 1.14 & & $6.038-6.462$ \\
\hline Two or more family stress factors/Girl (17) & $7.003^{\mathrm{a}}$ & 1.13 & & $6.462-7.543$ \\
\hline Two or more family stress factors/Boy (18) & $6.156^{\mathrm{a}}$ & 1.05 & & $5.669-6.643$ \\
\hline Family stress/siblings & & & $P=0.052$ & \\
\hline No or one family stress factor/no or one sibling (144) & $6.230^{\mathrm{a}}$ & 1.02 & & $6.061-6.398$ \\
\hline No or one family stress factor/two or more sibling (66) & $6.187^{\mathrm{a}}$ & 1.01 & & $5.943-6.430$ \\
\hline Two or more family stress factors/no or one sibling (21) & $6.213^{\mathrm{a}}$ & 1.03 & & $5.772-6.655$ \\
\hline Two or more family stress factors/two or more siblings (14) & $6.945^{\mathrm{a}}$ & 1.10 & & $6.366-7.524$ \\
\hline
\end{tabular}

a. Covariates appearing in the model are evaluated for age at diagnosis $=8.9876$.

travenous treatment, in line with the Swedish national care program [1]. This is well above the reported $37.5 \%$ of children receiving insulin in Germany and Austria, where the majority of children receive intravenous insulin for management of diabetic ketoacidosis [27]. Acidosis at diagnosis is associated with low beta cell function and high HbA1c [28]. Thus, children initially receiving intravenous insulin treatment had more episodes with hypoglycaemia during the first two weeks compared to children treated with subcutaneous insulin after onset of type 1 diabetes [27].

A further aim was to investigate if social factors, recorded at diagnosis influenced metabolic control. We found a significant difference for girls, living in families with more family stress, when looking at mean $\mathrm{HbAlc}$ over the two year period. Parental support has been shown to be an independent factor for adolescent girls and parental relationships ware suggested to be more strongly associated with the mental health of adolescent females than males $[29,30]$. Family stress factors in the present study were limited to the information available from patient's records. Each family saw a social worker during the initial hospital stay who recorded details of home environment. The validity of social factors was however limited as it was not possible to weight the factors in relation to families' experiences and should therefore be interpreted carefully. Social supports, educational level and socio-economic statuses ware not available but are known to be important factors when considering the child's risk to develop poor metabolic control [14,16,31].

When factors related to family stress were dichotomized, a breakpoint with no family stress factor and one or more family stress factors were considered to obtain more equal groups. In the group with one family stress factor, the single stress factor was mainly separated parents. A subgroup analysis was chosen instead to evaluate the influence of parents' cohabitation on HbAlc. Interestingly, when family stress, that sometimes follows a separation was excluded, there was no difference in the child's mean HbAlc for children where the parents lived together or were separated. These findings might not be in contrast to Swift's results that found children living with their biological parents had lower HbA1c compared to alternative family arrangements [17] since the results were explained by less social stress and more cohesive family environment [32]. In spite of the fact that groups were small when factors related to family stress were analysed, they were close to significant and may have led to false conclusions concerning non-significant differences. An interesting finding was that family stress did not predict hospital stay which is recommended by the Swedish care program [1] in order to support family out of their needs and possibilities to handle the new situation.

In conclusion, factors of importance for the child's long-term metabolic control need to be further investigated so the initial management can be tailored to each individual family's needs. This would imply an effective 
utilization of both families' and health care resources.

\section{Acknowledgment}

We would like to thank Per Nyberg for statistic counselling and Elisabeth Crang-Svalenius for reviewing the English language.

\section{REFERENCES}

[1] S. Sjöblad, "Pediatric and Adolescent Diabetes," A national care program by the Swedish society for diabetology and endocrinology, (Barn-och Ungdomsdiabetes Vårdprogram utarbetat inom Svenska barnläkarföreningens sektion för endokrinologi och diabetes) 2nd Edition, Studentlitteratur, Lund, 2008.

[2] R. A. Hirasing, H. M. Reeser, R. R. de Groot, D. Ruwaard, S. van Buuren and S. P. Verloove-Vanhorick, "Trends In hospital Admissions Among Children Aged 0-19 Years with Type I Diabetes in The Netherlands," Diabetes Care, Vol. 19, No. 5, 1996, pp. 431-434.

[3] T. Simell, O. Simell and H. Sintonen, "The First Two Years of Type 1 Fiabetes in Children: Length of the Initial Hospital Stay Affects Costs But not Effectiveness of Care," Diabetic Medicine, Vol. 10, No. 9, 1993, pp. 855-862.

[4] L. M. Siminerio, D. Charron-Prochownik, C. Banion and B. Schreiner, "Comparing Outpatient and Inpatient Diabetes Education for Newly Diagnosed Pediatric Patients," The Diabetes Educator, Vol. 25, No. 6, 1999, pp. 895-906.

[5] J. N. Kostraba, E. C. Gay, M. Rewers, H. P. Chase, G. J. Klingensmith and R. F. Hamman, "Increasing Trend of Outpatient Management of Children with Newly Diagnosed IDDM. Colorado IDDM Registry, 1978-1988," Diabetes Care, Vol. 15, No. 1, 1992, pp. 95-100.

[6] P. G. Swift, J. R. Hearnshaw, J. L. Botha, G. Wright, N. T. Raymond and K. F. Jamieson, "A Decade of Diabetes: Keeping Children Out of Hospital," British Medicine Journal, Vol. 307, No. 6896, 1993, pp. 96-98.

[7] C. Clar, N. Waugh and S. Thomas, "Routine Hospital Admission Versus Out-patient or Home Care in Children at Diagnosis of Type 1 Diabetes Mellitus," Cochrane Database Syst Rev, Vol. 2, 2007, pp. CD004099.

[8] V.C. Angus and N. Waugh, "Hospital Admission Patterns Subsequent to Diagnosis of Type 1 Diabetes in Children : A Systematic Review," BMC Health Services Research, Vol. 7, 2007, p. 199.

[9] D. N. Lessing, P. G. Swift, M. A. Metcalfe and J. D. Baum, "Newly Diagnosed Diabetes: a Study of Parental Satisfaction," Archives of Disease in Childhood, Vol. 67, No. 8, 1992, pp. 1011-1013.

[10] S. C. Shah, J. I. Malone and N. E. Simpson, "A Randomized Trial of Intensive Insulin Therapy in Newly Diagnosed Insulin-dependent Diabetes Mellitus," The New England Journal of Medicine, Vol. 320, No. 9, 1989, pp. 550-554.

[11] O. Schnell, B. Eisfelder, E. Standl and A. G. Ziegler, "High-dose Intravenous Insulin Infusion Versus Intensive
Insulin Treatment in Newly Diagnosed IDDM," Diabetes, Vol. 46, No. 10, 1997, pp. 1607-1611.

[12] T. Simell, E. A. Kaprio, J. Maenpaa, J. Tuominen and O. Simell, "Randomised Prospective Study of Short-term and Long-term Initial Stay in Hospital by Children with Diabetes Mellitus," Lancet, Vol. 337, No. 8742, 1991, pp. 656-660.

[13] E. L. Schor, "Family Pediatrics: Report of the Task Force on the Family," Pediatrics, Vol. 111, No. 6, 2003, pp. 1541-1571.

[14] G. A. Forsander, J. Sundelin and B. Persson, "Influence of the Initial Management Regimen and Family Social Situation on Glycemic Control and Medical Care in Children with Type I Diabetes Mellitus," Acta Paediatrica, Vol. 89, No. 12, 2000, pp. 1462-1468.

[15] S. J. Thompson, W. F. Auslander and N. H. White, "Comparison of Single-mother and Two-parent Families on Metabolic Control of Children with Diabetes," Diabetes Care, Vol. 24, No. 2, 2001, pp. 234-238.

[16] R. Viner, M. McGrath, and P. Trudinger, "Family Stress and Metabolic Control in Diabetes," Archives of Disease in Childhood, Vol. 74, No. 5, 1996, pp. 418-421.

[17] E. E. Swift, R. Chen, A. Hershberger and C. S. Holmes, "Demographic Risk Factors, Mediators, and Moderators in Youths' Diabetes Metabolic Control," Annals of Behavioral Medicine, Vol. 32, No. 1, 2006, pp. 39-49.

[18] R. Hanas, K. C. Donaghue, G. Klingensmith and P. G. Swift, "ISPAD Clinical Practice Consensus Guidelines 2009 Compendium. Introduction," Pediatric Diabetes, Vol. 10, No.(Suppl. 12), 2009, pp. 1-2.

[19] SWEDIABKIDS, "The Swedish Childhood Diabetes Registry,"March 2010. https://www.ndr.nu/ndr2/

[20] B. Floderus, M. Hagman, G. Aronsson, S. Marklund and A. Wikman, "Work Status, Work Hours and Health in Women with and without Children," Occupational and Environmental Medicine," Vol. 66, No. 10, 2009, pp. 704-710.

[21] DCCT Research Group, "Effect of Intensive Diabetes Treatment on the Development and Progression of Long-term Complications in Adolescents with InsulinDependent Diabetes Mellitus: Diabetes Control and Complications Trial," The Journal of Pediatrics, Vol. 125, No. 2, 1994, pp. 177-188.

[22] W. Hoelzel, C. Weykamp, J. O. Jeppsson, K. Miedema, J. R. Barr, I. Goodall, T. Hoshino, W. G. John, U. Kobold, R. Little, A. Mosca, P. Mauri, R. Paroni, F. Susanto, I. Takei, L. Thienpont, M. Umemoto and H. M. Wiedmeyer, "IFCC Reference System for Measurement of Hemoglobin A1c in Human Blood and the National Standardization Schemes in the United States, Japan, and Sweden:Amethod-comparison Study," Clinical Chemistry, Vol. 50, No. 1, 2004, pp. 166-174.

[23] F. Lombardo, M. Valenzise, M. Wasniewska, M. F. Messina, C. Ruggeri, T. Arrigo and F. De Luca, "Twoyear Prospective Evaluation of the Factors Affecting Honeymoon Frequency and Duration in Children with Insulin Dependent Diabetes Mellitus: the key-role of Age 
at Diagnosis," Diabetes, Nutrition \& Metabolism, Vol. 15, No. 4, 2002, pp. 246-251.

[24] G. Forsander, B. Persson, J. Sundelin, E. Berglund, K. Snellman and R. Hellstrom, "Metabolic Control in Children with Insulin-dependent Diabetes Mellitus 5 y after Diagnosis. Early Detection of Patients at Risk for Poor Metabolic Control," Acta Paediatrica, Vol. 87, No. 8, 1998, pp. 857-864.

[25] J. Sundelin, G. Forsander and S. E. Mattson, "FamilyOriented Support at the Onset of Diabetes Mellitus: a Comparison of two Group Conditions During 2 years Following Diagnosis," Acta Paediatr, Vol. 85, No.1, 1996, pp. 49-55.

[26] K. Hermansen, P. Fontaine, K. K. Kukolja, V. Peterkova, G. Leth and M. A. Gall, "Insulin Analogues (Insulin Detemir and Insulin Sspart) Versus Traditional Human Insulins (NPH insulin and regular human insulin) in Basal-bolus Therapy for Patients with Type 1 Fiabetes," Diabetologia, Vol. 47, No. 4, 2004, pp. 622-629.

[27] A. Herbst, C. L. Roth, A. G. Dost, R. Fimmers and R. W. Holl, "Rate of Hypoglycaemia and Insulin Dosage In Children during the Initial Therapy of Type 1 Diabetes Mellitus", European Journal of Pediatrics, Vol. 164, No. 10, 2005, pp. 633-638.
[28] J. Komulainen, R. Lounamaa, M. Knip, E. A. Kaprio and H. K. Akerblom, "Ketoacidosis at the Diagnosis of Type 1 (insulin dependent) Diabetes Mellitus is Related to Poor Residual Beta Cell Function. Childhood Diabetes in Finland Study Group," Archives of Disease in Childhood, Vol. 75, No. 5, 1996, pp. 410-415.

[29] E. Bru, T. A. Murberg and P. Stephens, "Social Support, Negative Life Events and Pupil Misbehaviour Among Young Norwegian Adolescents," Journal of Adolescence, Vol. 24, No. 6, 2001, pp. 715-727.

[30] V. S. Helgeson, L. Siminerio, O. Escobar, and D. Becker, "Predictors of Metabolic Control Among Adolescents with Diabetes: a 4-year Longitudinal Study," Journal of Pediatric Psychology, Vol. 34, No. 3, 2009, pp. 254-270.

[31] S. Overstreet, C. S. Holmes, W. P. Dunlap and J. Frentz, "Sociodemographic Risk Factors to Disease Control in Children with Diabetes," Diabetic Medicine, Vol. 14, No. 2, 1997, pp. 153-157.

[32] M. Wrigley and R. Mayou, "Psychosocial Factors and Admission for Poor Glycaemic Vontrol: a Study of Psychological and Social Factors in Poorly Controlled Insulin Dependent Diabetic Patients," Journal of Psychosomatic Research, Vol. 35, No. 2-3, 1991, pp. 335-343. 